\title{
Mengenal Beta Keton, Penanda Diabetes Tipe 1 pada Sensor Elektrokimia
}

\author{
Patria Pari Agnes \\ Program Studi Sarjana Farmasi, Fakultas Farmasi, Universitas Padjadjaran, Sumedang, 45363 \\ email: patria.sombo11@gmail.com
}

\begin{abstract}
Abstrak :
Dewasa ini, diabetes mulai menjadi permasalahan global, dimana jumlah penderitanya terus mengalami peningkatan tiap tahunnya. Maraknya kasus diabetes ini mendorong dilakukannya pergerakan guna mengembangkan suatuperangkat sederhana yang mampu mendeteksi kadar gula darah. Dalam mini review ini dibahas potensi beta keton sebagai penanda diabetes tipe 1 pada sensor elektrokimia. Dijelaskan pula kelebihan dan kekurangannya.
\end{abstract}

Kata kunci : beta keton, diabetes tipe 1, sensor elektrokimia

\section{Outline}

- Pendahuluan

- Diabetes ketoasidosi

- Beta keton

- Prinsip Kerja Sensor Elektrokimia

\section{Pendahuluan}

Dewasa ini, diabetes mulai menjadi permasalahan global, dimana jumlah penderitanya terus mengalami peningkatan tiap tahunnya. Bahkan, IDF memprediksikan bahwa akan terdapat peningkatan kasus diabetes yang signifikan di dunia, hingga mencapai 642 juta kasus pada 2040.

Pola hidup yang semakin tidak sehat dan maraknya hidangan instan menjadi faktor cukup penting dalam perkembangan penyakit ini. Maraknya kasus diabetes ini mendorong dilakukannya pergerakan guna mengembangkan suatuperangkat sederhana yang mampu mendeteksi kadar gula darah.

\section{Diabetes ketoasidosi}

Diabetes ketoasidosis adalah komplikasi dari diabetes tipe 1 dimana tubuh kekurangan insulin dan banyak terjadi pada usia remaja. Ciri-ciri dari diabetes ketoasidosis adalah hiperglikemia (defisiensi insulin sehingga glukosa tidak dapat masuk pada sel). Ciri-ciri selanjutnya adalah ketosis dan asidosis, dimana pada saat defisiensi insulin, hormone akan teraktivasi sehingga memicu lipolysis pada jaringan lemak.

Hasil dari lipolysis akan meningkatkan kadar asam lemak dan gliserol. Hati akan menstimulasi glucagon untuk mengoksidasi asam lemak untuk menjadi badan keton seperti beta-hydroxybutyrate dan acetoacetate. 
Ciri-ciri yang ketiga adalah dehidrasi karena tingginya kadar gula dalam darah dapat meningkatkan keluarnya cairan dari dalam sel ke luar sel. Ciri-ciri yang terakhir ialah ketidakseimbangan kandungan elektrolit dalam darah. Kalium merupakan elektrolit yang sangat terpengaruh pada Diabetes ketoasidosis.

Asidosis menyebabkan ion hydrogen berpindah dari cairan luar sel menuju cairan dalam sel. Perpindahan hydrogen ini memicu perpindahan kalium ke luar sel sehingga kalium akan masuk ke urin dan sel kekurangan potassium (Oakes dan Cole, 2007).

\section{Beta Keton}

Beta-Hidroksibutirat atau yang biasa disebut dengan Keton Body (beta keton). Keton Body berhubungan dengan penyakit diabetes tipe I. Diabetes Ketoasidosis biasanya terjadi pada fase akut dari penyakit diabetes. Konsentrasi keton normal dalam darah adalah 0,03-0,5 $\mathrm{mmol} / \mathrm{L}$.

\section{Prinsip Kerja Sensor Elektrokimia}

Umumnya pengujian keton dalam urin menggunakan test strip atau dipstick KetoChecks. Test strip ini menentukan keton dengan membandingkan perbedaan warna secara visual antara warna pada test strip dengan warna pada label wadahnya. Test ini menggunakan reaksi antara keton (acetoacetic acid) dengan sodium nitroprusside pada kondisi basa kuat. Warna pink menunjukan hasil negatif dan warna pink-ungu menunjukan hasil positif.

Keterbatasan dari pengujian ini adalah rendahnya akurasi dari hasil pengujian yang hanya berdasarkan interpretasi visual pengamat (FDA, 2003).

Perangkat elektrokimia ini digunakan untuk menghitung kadar gula darah melalui pengecekan kadar keton dalam darah dengan memanfaatkan Electrochemical Dongle yang disambungkan pada smartphone menggunakan OTG dan juga strip sekali pakai.

Strip elektrokimia ini sendiri berperan sebagai biosensor yang menkonversikan konsentrasi keton menjadi arus listrik yang kemudian dibaca dongle. Dimana, spesifisitas strip ini ditentukan oleh selektivitas $\beta$ - hydroxybutyrate dehydrogenase yang konsentrasinya berbanding lurus dengan kadar blood ketone.

$\beta$-hydroxybutyrate dehydrogenase sendiri adalah enzim spesifik yang akan mengkatalis pengubahan $\beta$-hydroxybutyrate menjadi acetylacetic acid. Dengan mengaplikasikan 200 $\mathrm{mV}$ direct current (DC) antara elektroda kerja dan counter electrode reaksi ini akan terjadi dan disaat yang sama NADH dioksidasi menjadi NAD+ dan juga terjadi reduksi $\mathrm{Fe}(\mathrm{III})$ menjadi $\mathrm{Fe}(\mathrm{II})$.

Transfer elektron yang terjadi akan diikuti oleh adanya aliran arus yang kemudian akan diteruskan dan dibaca langsung oleh dongle dengan ectronic contact juga pada strip. Arus tersebut kemudian dipetakan menjadi ukuran konsentrasi $\beta$-hydroxybuty dalam darah dan secara langsung ditampilkan dan di simpan dalam smartphone. 
Elektroda pada perangkat ini terletak pada strip yang berperan sebagai biosensor, dimana pada tahap awal reaksi elektrokimia, elektron akan terakumulasi dan kemudian akan ditransfer ke permukaan elektroda kerja di bawah proses reaksi yang dikatalis oleh enzim spesifik. Karena proses katalis dari enzim, reaksi ini akan berlangsung dengan jangka yang sangat pendek. Kemudian arus akan meluruh secara eksponensial.

Peluruhan arus ini terjadi karena menurunnya jumlah enzim di permukaan elektroda kerja, hingga mencapai kondisi dimana arus mencapai level yang relatif stabil.

Pada alat ini digunakan elektrokimia analyzer yang mengunakan test strip sekali pakai untuk mendeteksi kadar keton dalam darah. Test strip dihubungkan dengan electrochemical dongle atau suatu wadah yang didalannya terdapat bagian yang berfungsi untuk analisis dan menghitung arus yang ditimbulkan atau chemochemical analyzer yang berupa chronoamperometric.

Electrochemical dongle dihubungkan dengan OTG(On-The Go) atau kabel USB yang menghubungkan sumber energi dari smartphone dengan rangkaian alat. Kadar yang didapat dilihat dari tampilan smartphone.

Strip yang mengandung enzim $\beta$ - hydroxybutyrate dibuat dengan cara melapisi polyethlene Terephtalete (PET) dengan tinta hitam. PET selanjutnya dipanaskan bersamaan dengan elektroda karbon selama 40 menit pada suhu $69^{\circ} \mathrm{C}$.

Ditempelkan stick double layer pada PET untuk menyisakan celah kerja. Pada celah kerja tersebut selanjutnya direndam dengan enzim $\beta$-hydroxybutyrate dan dipanaskan pada tunel ovan pada suhu $35-450 \mathrm{C}$ selama 30 menit. Setelah enzim menempel sempurna test strip dilapisi dengan lapisan hidrofilik sebagai cover atau pelindung test strip.

Hasil pengukuran menggunakan alat ini akan ditampilkan pada layar smartphone yang secara bersamaan dapat disinkronkan dengan data kesehatan pribadi pasien tersebut. Dimana konsentrasi keton dalam darah akan berbanding lurus dengan arus yang dipetakan kedalam kurva chronoamperometric (Guo, 2017).

Arus yang dikarakterisasi ditentukan dengan rata-rata nilai sampel saat interval 5 dan 5,1 detik. Setelah sepuluh detik, konsentrasi keton darah ditampilkan di smarthphone (Guo, 2017). Untuk diagnosis ketosis, pasien yang didiagnosis diabetes ketoasidosis berdasarkan tiga faktor: (1) $\beta$-hydroxybutyrate darah> $3 \mathrm{mmol} / \mathrm{L}$; (2) glukosa darah> $13,9 \mathrm{mmol} / \mathrm{L}$; (3) HCO3 darah <15-18 mmol / L atau pH darah arteri <7.3 (Guo, 2017).

\section{Kesimpulan}

Alat elektrokimia dengan beta keton untuk penanda diabetes tipe 1 mempunyai beberapa kelebihan yaitu harganya yang murah (kurang dari Rp 140.000,-), alatnya yang simpel membuatnya mudah dibawa kemana-mana dan juga mempunyai sensitifitas yang tinggi karena dapat mendeteksi $0,001 \mathrm{mmol} / \mathrm{L}$ selain itu alat ini juga bekerja spesifik karena terdapat enzim beta hidroksibutirat dehidrogenase. namun adanya hematocrit dalam darah dapat menyebabkan terganggunya hasil pengukuran. 


\section{Daftar Pustaka}

FDA. 2003. Summary of the 510 (k) Safety and Effectiveness. Tersedia online di https://www.accessdata.fda.gov/cdrh_docs/pdf3/k033114.pdf [Diakses pada 1 Juni 2019].

Oakes, E.E., dan Cole, L. 2007. Diabetic Ketoacidosis. Tersedia online di https://www.aci.health.nsw.gov.au/

data/assets/pdf_file/0008/220679/nepean_guide_DKA_2007.pdf [ Diakses pada 27 Mei 2019] .

Guo, J. 2017. Smartphone-Powered Electrochemical Dongle for Point-of-Care Monitoring of Blood $\beta$-Ketone. Analytical Chemistry.

University of Southampton.2017.What happens when insulin levels run low in type 1 diabetes. Tersedia online di https://www.futurelearn.com/courses/understandinginsulin/0/steps/22487 